\title{
Estimation of the Global-Scale Ecological Footprint within the Framework of STIRPAT Models: The Quantile Regression Approach
}

\section{Küresel Ölçekte Ekolojik Ayak İzinin STIRPAT Modelleri Çerçevesinde Tahmini: Kantil Regresyon Yaklaşımı}

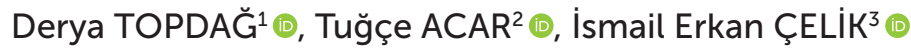

\begin{abstract}
Despite the fundamental role of human-induced forces in global environment having changed, knowledge about the specific factors that cause these impacts is limited and uncertainties remain. In this respect, the ecological footprint emerges as a concept used to emphasize both the apparent unsustainability of current practices and the inequalities in resource consumption among countries. The ecological footprint provides a method for measuring how much land can support the consumption of natural resources and provides a precise measure of human impact on the world. In recent years, sustainable development and biological capacity debate has mainly revolved around factors affecting the ecological footprint and approaches to improving environmental quality. Therefore, it is important to determine which factors affect the global ecological footprint. For this aim, a cross-section analysis was carried out with the quantile regression approach applied within the framework of the STIRPAT model structure for 154 countries that were allocated according to their income levels in 2016, taking into account current data. According to the quantile regression findings, the coefficients of the welfare and financial development index are positive and statistically significant. It has been concluded that the population decreases the amount of ecological footprint per person, thus, increasing the total ecological footprint. In addition, it has been determined that the density of the service sector negatively affects the ecological footprint.
\end{abstract}

Keywords: Ecological footprint, STIRPAT model, Quantile regression

JEL Classification: C01, C13, Q51

\section{Öz}

Insan kaynaklı itici güçlerin küresel çevresel değişimde oynadığı temel role rağmen, bu etkilere neden olan belirli
DOI: 10.26650/ISTJECON2020-815891

${ }^{1}$ Research Assistant, Bandırma Onyedi Eylül

University, Faculty of Economics and Administrative Sciences, Department of Econometrics, Balıkesir, Turkey

${ }^{2}$ Research Assistant, Beykent University, Faculty of Economics and Administrative Sciences, Department of Economics, Istanbul, Turkey

${ }^{3}$ Assistant Professor, Doğuş University, Faculty of Economics and Administrative Sciences, Department of Economics, İstanbul, Turkey

ORCID: D.T. 0000-0002-2644-5054;

T.A. 0000-0001-9223-0089;

I.E.Ç. 0000-0002-2274-0750

\section{Corresponding author/Sorumlu yazar: Tuğçe ACAR, \\ Beykent University, Faculty of Economics and Administrative Sciences, Department of Economics, Istanbul, Turkey E-mail/E-posta: tugceacar@beykent.edu.tr}

Submitted/Başvuru: 24.10.2020

Accepted/Kabul: 01.12.2020

Citation/Atıf: Topdag, D., Acar, T., \& Celik, I.E. (2020). Estimation of the global-scale ecological footprint within the framework of STIRPAT models: the quantile regression approach. Istanbul Iktisat Dergisi - Istanbul Journal of Economics, 70(2), 339-358.

https://doi.org/10.26650/ISTJECON2020-815891 
etkenler hakkındaki bilgi sınırlıdır ve belirsizlikler devam etmektedir. Bu bağlamda, ekolojik ayak izi hem mevcut uygulamaların görünürdeki sürdürülemezliğini hem de ülkeler arasında kaynak tüketimindeki eşitsizlikleri vurgulamak için kullanılan bir kavram olarak ortaya çıkmaktadır. Ekolojik ayak izi, ne kadar arazinin doğal kaynakların tüketimini destekleyebileceğini ölçmek için bir yöntem sağlar ve insanın dünya üzerindeki etkisini açık bir biçimde ortaya koyan bir ölçü sağlamaktadır. Son yıllarda sürdürülebilir kalkınma ve biyolojik kapasite tartışmaları, esas olarak ekolojik ayak izini etkileyen faktörler ve çevresel kaliteyi iyileştirme yaklaşımları etrafında dönmektedir. Bu nedenle, küresel ekolojik ayak izini etkileyen faktörlerin belirlenmesi
Önemlidir. Bu amaçla 2016 yılında gelir düzeylerine göre tahsis edilen 154 ülke için STIRPAT model yapısı çerçevesinde uygulanan kantil regresyon yaklaşımı ile güncel veriler dikkate alınarak yatay kesit analizi yapılmıştır. Kantil regresyon bulgularına göre; refah ve mali gelişme endeksinin katsayıları pozitiftir ve istatistiksel olarak anlamlıdır. Nüfusun kişi başına düşen ekolojik ayak izi miktarını azalttığı, böylece toplam ekolojik ayak izini artırdığı sonucuna varılmıştır. Ayrıca hizmet sektörünün yoğunluğunun ekolojik ayak izini olumsuz etkilediği tespit edilmiştir.

Anahtar kelimeler: Ekolojik ayak izi, STIRPAT model, Kantil regresyon

JEL Sınıflaması: C01, C13, Q51 


\section{Introduction}

In recent years, it has become more apparent that people have changed the global environment significantly. People have changed the atmosphere's chemical structure via the emmission of substances such as carbon dioxide and greenhouse gases such as methane that make the ozone layer thinner. Consequently, the extinction of species has accelerated (York, Rosa, \& Dietz, 2003a, p. 352). Concerns regarding the sustainability of current economic and social implications are increasing despite important improvements in ecologic efficiency like producing for each dollar economic output with less amount of input and pollution output in last decades (Hayden \& Shandra, 2009, p. 575). Sustainable development has become an important subject since the World Summit in Rio in the year 1992 and various models, methodologies and indicators have been presented to quantify sustainable development. One of the indicators, ecological footprint (EF) is calculated by Wackernagel and Rees (1996) and has drawn much attention and widely used (Jia, Deng, Duan, \& Zhao, 2009, p. 2819).

The ecological footprint is a concept of a comprehensive measure for a population's natural resource demand that can be stated with a single unit as area of abundant land in hectares. (Hayden \& Shandra, 2009, p. 584). This concept is an ecological economic development initiative based on biophysics that converges reality better than many economic models and it clearly highlights the human impact on the globe. The ecological footprint is a measure that helps to forecast ecological assets needed to absorb especially carbon emission wastes and to produce the natural resources (including plant-based food and fiber products, animal husbandry and fishery, forestry, and urban infrastructure) a nation consumes ("world Footprint Network", n.d.). The ecological footprint area tracks the demand of humans from nature and this demand is composed of six area types. These six area types are: production of animal products and grazing land to raise farm animals, forestry areas for wood production, sea areas for fishery, land for housing and infrastructure, forestry area needed to absorb the carbon dioxide emissions caused by energy consumption ("World Wide Fund for Nature-Deutschland", 2016, p. 20). In general, the higher the ecological footprint 
in a country with a specific population, the more the environmental problems the region will have and the higher the harm done to the environment.

The regeneration capability of ecosystems is called biological capacity. Ecological Footprint and biological capacity provide an experimental measure that indicates whether humans will continue to live in the world and shows how this relationship changes over time. Biological capacity has increased by roughly $27 \%$ in the last fifty years with the changes and the technological advancements to inland applications. However, in the meantime, the ecological footprint has increased by approximately $190 \%$ with fast population growth and consumption (Grooten \& Almond, 2018, p. 28-30). The movement of global ecological footprint is depicted below in Figure 1:

Figure 1. Global Ecological Footprint

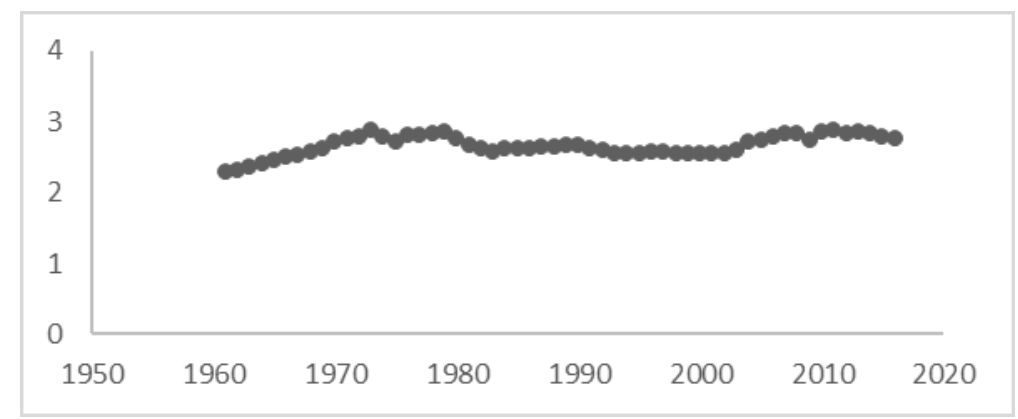

Source: (https://www.footprintnetwork.org/our-work/ecological-footprint/).

Ecological deficit arises when a population's ecological footprint exceeds the regions biological capacity. This could mean that demand of humans both for products in the sea and on land exceeds the quantity that the region's ecosystem can renew. Consequently, sustainability can not be achieved as it is impossible to close the global scale ecological deficit and environmental problems arise such as over usage of the environment ("Global Footprint Network", n.d.).

Vast economic models rarely consider resource constraints. Substantial changes are required both in production and consumption to generate a more sustainable system (Grooten \& Almond, 2018, p. 29). In recent years, a consensus started to 
form about the fundamental causes of human-led environmental deterioration. Generally, welfare (GDP) and population are perceived as the main locomotives of environmental problems and the number of studies supporting this argument is increasing (York et al., 2003c; Jia et al., 2009).

Despite the consensus that humans are changing the global environment in terms of climate change, green gas emissions, emissions of substances that make the ozone layer thinner, extinction of species and ecological openness significantly, the uncertainty about specific elements that cause these effects prevails. The ecological footprint provides a fruitful computation for the analysis of human activities and environmental impact. This study aims to analyze the effects of human activities in a global scale over the environment via a STIRPAT model framework. The following parts of the study are as follows; STIRPAT model, followed by a comprehensive literature review, data and methodology is introduced, and findings and recommendations are finally discussed.

\section{The STIRPAT Model}

In most of the recent economic or scientific research studies, the development of population, welfare and technology has been assessed with the environmental effect. From this aspect, Ehrlich and Holdren (1971) are among the pioneers who aim to explain the dynamics of environmental effect, population and welfare of the people. The formula of this so called relation was initially identified as IPAT. The research results have provided evidence that the population has adverse effects on the environment and welfare is becoming a fundamental driving force for $\mathrm{CO}_{2}$ emission. In addition to this, Dietz and Rosa (1997) have stated that people's activities do also affect the environment. From this respect, the activities of people are divided into three main powers; Population (P), Welfare $(A)$ and technology that defines production standards $(T)$. The above mentioned model is stated here below:

$$
I=P \times A \times T
$$

But this model ignores the non-linear relations among variables, and it is evaluated as a simple statistical structure for complex structures. Thus, the model 
is generalized mathematically (Wang, Zhao, Zheng, \& Hu, 2017, p. 3). Generalization of the model done by Dietz and Rosa (1997) as a stochastic regression overpopulation, welfare and technology and experimental hypothesis testing is allowed in the model. The expanded model is as follows:

$$
I_{i}=\alpha P_{i}^{\beta} A_{i}^{\gamma} T_{i}^{\delta} \varepsilon_{i}
$$

$\alpha$ constant term, $\beta, \gamma, \delta$ parameters to be forecasted and $\varepsilon$ is the error term. A, represents welfare and is measured with GDP. P represents population and T represents technological variables such as production industry and energy efficiency. These variables vary depending on the country under study. When natural logarithms are taken on both sides of the equation, the model is stated as:

$$
\begin{gathered}
\ln I_{i}=\alpha_{0}+\beta \ln \left(P_{i}\right)+\gamma \ln \left(A_{i}\right)+\delta \ln \left(T_{i}\right)+\mu_{i} \\
\ln \alpha=\alpha_{0} \\
\ln \varepsilon_{i}=\mu_{i}
\end{gathered}
$$

Various variables are used to represent technology in the literature. The scale and structure can differentiate population factors. The annual population meas and urbanization rate is frequently used to serve for this purpose. Thus, while the STIRPAT model structure analyzes the effects of independent variables on the environment, it also provides opportunities for different analysis by expanding the model as the model's mathematical structure provides an edge and technology variable is not constant.

\section{Literature Review}

There are numerous studies aiming to determine the ecological footprint, which is the measure of human influence on the environment, and it provides an opportunity for the measurement and management of the usage of economic resources; individual lifestyles; the discovery of sustainability for nations. The relevant literature is presented here below. 
York et al. (2003a) have examined the relation between $\mathrm{CO}_{2}$ emission and energy footprint with samples representing more than $97 \%$ of the world population and economic output within a STIRPAT model framework. Dependent variables are the $\mathrm{CO}_{2}$ emission arising from the fossil fuel burn and cement production in the year 1996 and the energy footprint in terms of hectares for 1999. The data set consists of 146 samples of data for 1999 for $\mathrm{CO}_{2}$ emission analysis and 138 samples of data for energy footprint analysis for countries that have available data. Independent variables are determined as GDP per capita, urbanization rate, population density in rural areas and share of industrial sector in GDP for different models proposed. As a result of the analysis, only urbanization rate is found to be insignificant and the remaining independent variables are found to be positively effective on both $\mathrm{CO}_{2}$ emmission and energy footprint and they are statistically significant.

York et al. (2003b) used the STIRPAT model with cross-section data for the year 1991 for 137 countries. The study aimed to provide evidence for the influence of urbanization rate, GDP, share of industrial sector in GDP and other factors on $\mathrm{CO}_{2}$, $\mathrm{CH}_{4}$ emissions and their compound GWP. To control the climate effect, a puppet variable indicating whether the country belongs to a tropical region is included. It has been found via OLS regression that population and urbanization are significantly effective on $\mathrm{CH}_{4}$ emission. The results also show that the squared values of GDP and urbanization variables are insignificant and contradict the expectations of the Environmental Kuznets Hypothesis. As in the $\mathrm{CH}_{4}$ and $\mathrm{CO}_{2}$ analyses, total population is found to have an important effect on emmissions.

Rosa, York, and Dietz (2004) used six different environmental indicators for 142 countries for their cross-sectional analysis. Carbon dioxide $\left(\mathrm{CO}_{2}\right)$, methane $\left(\mathrm{CH}_{4}\right)$ emissions, substances that make the ozone layer thinner due to their effects on the atmospheric systems (ODS) and ecological footprint is among them. Findings for the year 1998 do not support Environmental Kuznets Hypothesis; however, it is stated that population is the most effective variable on environmental indicators.

Hayden and Shandra (2009) also studied the determinants of ecological footprint variable via a cross-sectional analysis for the year 2000. The sample was 
formed out of 45 countries, 19 of which are classified as high income; 22 of which, middle income and 4 are classified as low income countries. GDP per capita, annual working hours, output level per working hour, foreign trade, total population, urbanization and employment levels are found to have a positive effect on ecological footprint. Military expenditures and size of the services sector are found to be both statistically insignificant and a negative effect on ecological footprint.

Jia et al. (2009) used the partial least squares (PLS) method in order to determine the fundamental driving forces of ecological footprint for the Henan region of China for the period 1983-2006. According to the STIRPAT model, factors affecting ecological footprint are determined as the human population, GDP per capita, share of sectors other than the service sector in GDP, the square of GDP per capita, and the urbanization rate. Results indicate that the most influential factors are found to be population, GDP and share of sectors other than service sector in GDP. As a side note, coefficient of urbanization is found to be negative.

Dietz, Rosa, and York (2007) limited their sample to countries that have a population higher than one million so that smaller countries do not dominate the sample. Their cross-sectional data analysis for the year 2001 is as follows: size of population and welfare are the main driving forces of environmental factors, however, other pervasively accepted factors such as urbanization, economic structure and age distribution are found to have negligible effects. It has been also tested for the Environmental Kuznets Curve and contrary to the expectations of the hypothesis, it is stated that increasing welfare does not lead to better environmental factors.

Tang, Zhong, and Liu (2011) have investigated the factors affecting the ecological footprint in the Sichuan Province, China, using the Ridge regression method for 14 years between 1995 and 2008. For the STIRPAT model, the driving forces of the ecological footprint are population size, GDP per capita, GDP per capita in quadratic form, and the percentage of GDP from industry as the 
urbanization rate. The results show that the population is the main driver of ecological footprint change in Sichuan province, while urbanization and industrialization are also positively associated with the ecological footprint.

Bello, Solarin, and Yen (2018) investigated the determinatives of four different environmental degradation variables including ecological footprint, carbon footprint, water footprint and $\mathrm{CO}_{2}$ emission in the period of 1971-2016. GDP, GDP square, urbanization rate and renewable energy are determined as independent variables.

The VECM-based Granger causality test was used to explore the ARDL boundary test approach and direction to investigate the long-term relationships between these variables. The results showed evidence of an inverse U-shaped relationship between environmental degradation and real GDP. Evidence has also been found of a bi-directional causal relationship between real GDP and all environmental indices, and between urbanization and water footprint and carbon footprint per capita.

Başoğlu (2018) examined determining ecological footprint for the period 1971-2014 within the framework STIRPAT models for Turkey by the ARDL bounds testing method. GDP, total population, energy consumption, the share of industry and service sector in GDP and human capital index are selected as independent variables. As a result of the analysis, it was concluded that variables other than human capital index positively affect the ecological footprint when considered in terms of both long and short-term effects. It was also determined that the variable affecting the ecological footprint the most between these periods was energy consumption.

\section{Data Set}

The article investigates the determinatives of the ecological footprint in 2016, with the STIRPAT model in the framework of cross-sectional analysis, for a total of 154 countries, including 22 low, 41 upper-middle, 40 lower-middle, and 51 highincome groups. The dependent variable is chosen as the ecological footprint (I) 
per person in 2016, which is widely used in social sciences, an indicator of environmental impacts. To measure the welfare levels of countries (GDP), per capita gross domestic product $(A)$ is included in the model. The total population size (POP) is included in the analysis to control the impact of population size. Service intensity indicator (SVR) was added to the model to measure the impact of service sector activity $(T)$ on the environment as a percentage of GDP.

A negative relationship will be consistent with the hypotheses that emphasize improved modernization and change towards cleaner production patterns. In the economic model, it is assumed that a shift away from mining industries and manufacturing and towards services (e.g. banking, healthcare, information processing) can reduce environmental impact (Dietz et al., 2007). Finally, (FDI) financial development index was added to the model as a technology $(T)$ variable in the STIRPAT models approach. The explanations about the data set in the study are as follows:

Table 1: Data Set

\begin{tabular}{|l|c|c|}
\hline Variable & Description & Source \\
\hline EF & Ecological Footprint, Per Capita & Penn World Table \\
\hline GDP & GDP Per Capita (Constant 2010, \$) & WDI \\
\hline POP & Population, Total & WDI \\
\hline FDI & Financial Development Index & IMF \\
\hline SRV & Services, value added (\% of GDP) & WDI \\
\hline
\end{tabular}




\subsection{Methodology: Quantile Regression}

The success of a statistical method is related to the possibility of realistically testing the properties of the data. It is essential to have efficient methods and algorithms that can calculate different realistic solutions for such purposes. Accordingly, standard linear regression procedures show how the expected value of the dependent variable reacts to a change in an explanatory variable. It produces effective results depending on the provision of certain assumptions. For instance, income distributions are rarely normal. Observed on a firm basis, the distribution of annual remuneration for the chairman of the board tends to increase with firm size as an indicator of varying variance. Flexibility is provided to these assumptions by quantile regression. The quantile regression approach includes predicted changes for the entire distribution of the dependent variable. In other words, it allows the separate effects of the explanatory variable on different points of the dependent variable distribution (McMillen, 2013, p. 1). It is not the only area where it demonstrates its power in facing the variance problem that changes depending on the first applications. Due to its non-parametric nature, it is also a valid alternative in analyzing data characterized by different error distribution types (Davino, Furno, \& Vitocco, 2014, p. 22). Thus, the approach differs from traditional regression models thanks to its emphasis on distributions. Therefore, it is more suitable for analyzing the changes in the distribution of the dependent variable.

On the other hand, while the assumption of homogeneity for error term variance is in question in classical linear regression analysis, variability is allowed in quantile regression, and it does not contain an assumption for variance structure. Besides, in the presence of extreme values in the analyzed data set, it provides an advantage to take these values into account and give more effective results instead of excluding them from observation. While extreme values cannot be detected in linear regression analysis, regression lines in different quantities can observe extreme values (Çamurlu and Erilli, 2019, p. 18). 
Quantile regression model;

$$
Y_{i}=x_{i} \beta_{\vartheta}+e_{i}
$$

$\mathrm{x}_{\mathrm{i}}$ denotes the vector $\mathrm{k}+1$ dimensional argument.

It expresses the linear regression between the independent variables and the $\vartheta$. th quantile of the conditional distribution of the dependent variable. $\beta_{\vartheta}$ is the parameter vector of the $9^{\text {th }}$ quantile regression. In quantile regression, separate effects of the explanatory variable on different points of the dependent variable distribution are allowed. Therefore, the results obtained according to the estimated quantiles vary. The quantile level is usually denoted by $T$, and while $X$ is data, the conditionaliquantile of $Q_{t}(Y \mid X)$. Quantile level $T$ is the probability expression in the form of $\operatorname{Pr}\left(Y \leq Q_{t}(Y \mid X) \mid X\right)$. The entire conditional distribution can be defined with a selected t quantile level in the range of $(0,1)$ and in practice, usually $0.25,0.50$ and 0.75 quantile values are analyzed. The choice of the most suitable quantile depends on the data and the larger the data set, the more detail can be captured in the conditional distribution. The main features of quantile regression compared to classical linear regression are as follows:

Table 2: Comparison of Linear Regression and Quantile Regression

\begin{tabular}{|l|l|}
\hline Linear Regression & Quantile Regression \\
\hline Estimates the conditional mean $\mathrm{E}(\mathrm{Y} \mid \mathrm{X})$. & The conditional quantile $Q_{t}(\mathrm{Y} \mid \mathrm{X})$ predicts. \\
Valid when $\mathrm{N}$ is small & Sufficient data is needed \\
Normality assumption & Distribution is agnostic \\
Sensitive to extremes value & Resistant to extreme values. \\
Ease of calculation & Density of calculation \\
\hline
\end{tabular}

For the standard linear regression model:

$$
\mathrm{E}\left(y_{i}\right)=\beta_{0}+\beta_{1} x_{i 1}+\cdots+\beta_{p} x_{i p}
$$


$\mathrm{i}=1,2, \ldots \mathrm{n}$ and $\beta_{\mathrm{j}}$ parameters $\mathrm{j}=1,2, \ldots \mathrm{p}$ are based on least squares minimization.

$$
\min _{\beta_{0}, \beta_{1}, \ldots \beta_{p}} \sum_{i=1}^{n}\left(y_{i}-\beta_{0}-\sum_{j=1}^{p} x_{i j} \beta_{j}^{2}\right.
$$

On the other hand, for the quantile regression model,

$$
Q_{\tau}\left(y_{i}\right)=\beta_{0}(\tau)+\beta_{1}(\tau) x_{i 1}+\cdots+\beta_{p}(\tau) x_{i p}
$$

$\mathrm{i}=1,2, \ldots . \mathrm{n}$ for the $\beta_{0}(\tau)$ parameters minimization ;

$$
\begin{gathered}
\min _{\beta_{0}(\tau), \beta_{1}(\tau), \ldots, \beta_{p}(\tau)} \sum_{i=1}^{n} \rho_{\tau}\left(y_{i}-\beta_{0}(\tau)-\sum_{j=1}^{p} x_{i j} \beta_{j}(\tau)\right)^{2} \\
\rho_{\tau}(r)=\tau \max (r, 0)+(1-\tau) \max (-r, 0)
\end{gathered}
$$

$\mathrm{p}_{\mathrm{T}}(\mathrm{r})$, is called the control function. In addition, for each quantile level $\mathrm{T}$, the solution of the minimization problem gives a different set of regression coefficients.

\section{Experimental Study}

The article examines the determinatives of the ecological footprint variable, which is an environmental indicator, within the framework of the STIRPAT model. Firstly, the classical regression model estimation is given within the framework of the STIRPAT model. Since the Financial Development Index and the share of the services sector in GDP are fractional, the natural logarithm of the other variables is also taken to eliminate the scale difference. The general STIRPAT model, in which the mathematical form is made logarithmic, adapted to the study is expressed as follows:

$$
L N E F_{i}=c+\beta_{1} F D_{i}+\beta_{2} L N G D P_{i}+\beta_{3} S V R_{i}+\beta_{4} L N P O P_{i}+\varepsilon_{i}
$$

The results obtained from the classical regression for ecological footprint estimation are as follows: 
Table 3: Descriptive Statistics

\begin{tabular}{|l|c|c|c|c|c|}
\hline & LNEF & FD & LNGDP & LNPOP & SVR \\
\hline Observation & 154 & 154 & 154 & 154 & 154 \\
\hline Average & 0.938 & 0.340 & 8.625 & 16.107 & 54.649 \\
\hline Std.Dev. & 0.707 & 0.230 & 1.491 & 1.769 & 11.539 \\
\hline Min. & -0.701 & 0.046 & 5.393 & 11.457 & 14.747 \\
\hline Max. & 2.668 & 0.964 & 11.610 & 21.044 & 78.830 \\
\hline
\end{tabular}

Table 4: Ecological Footprint Estimation Results within the framework of STIRPAT Models: Classical Regression

\begin{tabular}{|c|c|}
\hline Independent Variable & Model 1 \\
\hline FD & $0.433^{*}$ \\
& {$[1.68]$} \\
\hline LNGDP & $0.397^{\star \star \star}$ \\
& {$[10.48]$} \\
\hline SVR & $-0.008^{\star *}$ \\
& {$[-2.60]$} \\
\hline LNPOP & $-0.064^{\star * *}$ \\
& {$[-3.29]$} \\
Constant & $-1.129^{* *}$ \\
& {$[-2.19]$} \\
F & $F(4,149)=138.20^{\star * *}$ \\
$\mathrm{R}^{2}$ & 0.78 \\
\hline
\end{tabular}

Note: ${ }^{*}{ }^{* *},{ }^{* * *}$ denote $10 \%, 5 \%$ and $1 \%$ significance level respectively. [ ] shows t values.

Whether the error terms are normally distributed, specification error and heteroskedasticity should be tested. If the error terms are not distributed normally and this information is not taken into account, we can produce misleading results. The results of Jarque-Bera (1981) for normality test, Ramsey Reset (1969) for specification error and Bresuch-Pagan (1979) test results for heteroskedasticity are as follows:

Table 5: Hypothesis Tests Results

\begin{tabular}{|c|c|}
\hline Test & Test Results \\
\hline Jarque-Bera & Chi2(2) $=0.545$ \\
& $(1.212)$ \\
\hline Ramsey Reset & $\mathrm{F}(3,146)=1.35$ \\
\hline
\end{tabular}




\begin{tabular}{|c|c|}
\hline & $(0.259)$ \\
Breusch- Pagan & Chi2(1)=0.54 \\
VIF & $(0.4637)$ \\
\hline
\end{tabular}

Note: Numbers in brackets are probability values.

According to the test results, normality assumption is provided. There is no defining error, there is no multicollinearity between variables, and there is no endogeneity problem with heteroskedasticity in the model. Except for this, the existence of extreme values in the model has been detected. If estimations are made without taking these values into account, the assumptions are broken in classical linear regression estimation. Thus, the use of robust estimation methods, that provide parameter-resistant and stable parameter estimates, provide insensitivity to deviations. Quantile regression is used in the analysis, which is one of the robust estimation methods and provides more detailed information as each quantile level is examined about the data set. Quantile regression is a robust method used against extreme values. Thanks to this method, information about the entire conditional distribution can be obtained. Accordingly, the quantile regression estimation results are as follows:

Table 6: Quantile Regression Results

\begin{tabular}{|c|c|c|c|}
\hline Variables & Model $2(\tau=0.25)$ & Model $3(\tau=0.50)$ & Model $4(\tau=0.75)$ \\
\hline FD & $\begin{array}{c}0.793^{\star \star} \\
{[2.27]}\end{array}$ & $\begin{array}{l}0.216 \\
{[0.66]}\end{array}$ & $\begin{array}{l}0.047 \\
{[0.16]}\end{array}$ \\
\hline & $\begin{array}{c}0.335^{\star \star \star} \\
{[6.52]}\end{array}$ & $\begin{array}{c}0.412^{\star \star \star} \\
{[8.51]}\end{array}$ & $\begin{array}{c}0.502^{\star \star \star} \\
{[11.37]}\end{array}$ \\
\hline SVR & $\begin{array}{c}-0.008^{*} \\
{[-1.94]}\end{array}$ & $\begin{array}{c}-0.013^{\star *} \\
{[-3.04]}\end{array}$ & $\begin{array}{c}-0.018 * * * \\
{[-4.77]}\end{array}$ \\
\hline LNPOP & $\begin{array}{c}-0.070 * * \\
{[-2.65]}\end{array}$ & $\begin{array}{c}-0.069 * * \\
{[-2.81]}\end{array}$ & $\begin{array}{c}-0.110 * * * \\
{[-4.86]}\end{array}$ \\
\hline Constant & -0.844 & -0.844 & -0.383 \\
\hline & {$[-1.21]$} & {$[-1.28]$} & {$[-0.64]$} \\
\hline Pseudo $\mathrm{R}^{2}$ & 0.57 & 0.58 & 0.55 \\
\hline Number of Observations & 154 & 154 & 154 \\
\hline
\end{tabular}

Note: ${ }^{*}{ }^{* *},{ }^{* * *}$ denote $10 \%, 5 \%$ and $1 \%$ significance level respectively. [ ] shows t values.

According to the quantile regression results, it was determined that the ecological footprint variable is affected by the variables of national income per capita and the total population for the examined $0.25,0.50$ and 0.75 quantiles. It 
has been determined that as the level of quantile increases, the effect of variables on the ecological footprint increases. The total population has a negative, it has been found that it increases the total ecological footprint while decreasing the area of ecological footprint per person. Thus, it is concluded that prosperity and population are the main driving forces affecting the ecological footprint. The density of the service sector was found to be negative and statistically significant for all quantiles. This result is consistent with the expectation that it will reduce the ecological footprint. It is concluded that when the share of the service sector in the GDP increases, the per capita ecological footprint area decreases. The financial development index has a significant effect on only 0.25 quantities and positively affects the ecological footprint. It was concluded that the financial development index affects only the ecological footprint with a low quantile value and increases the ecological footprint.

\section{Conclusion}

The quantitative analysis of the factors that trigger environmental problems within the framework of sustainable development is a subject of interest. Although there is scientific consensus about the root causes of environmental impacts on a global scale, uncertainties remain concerning the exact relationships. Therefore, the ecological footprint variable has been taken into account to analyze the impact of human activities on the environment. Accordingly, in this study, a cross-section data of 154 countries and the factors affecting the ecological footprint within the framework of the STIRPAT model were analyzed using quantile regression. When the analysis results were evaluated within the framework of the STIRPAT model, it is determined that population and welfare variables were factors that increase the ecological footprint. It is seen that these variables are statistically significant in all models.

On the other hand, it is found that the financial development index, which is one of the leading concepts for the economic development of countries, increases the ecological footprint. These positive findings on the welfare and financial development index and the environmental indicator may raise concerns about the unsustainability of current social and economic practices. Service intensity has 
a negative impact on the ecological footprint. This result can be interpreted as an indicator that the share of the heavy industry and manufacturing sector has shifted to the service sector such as banking, health sector and technology in recent years (Dietz et al., 2007). It is concluded that each person has an impact on the environment on a global scale, the amount of which depends on other factors. The results reveal that the effects of welfare and population variables on the environment, which are fundamental factors for sustainable development, should be reviewed. Therefore, sustainable economy model studies, renewable energy sources and laws protecting the environment should be strengthened.

Peer-review: Externally peer-reviewed.

Conflict of Interest: The authors have no conflict of interest to declare.

Grant Support: The authors declared that this study has received no financial support.

\section{References/Kaynaklar}

Başoğlu, A. (2018). STIRPAT modeli kapsamında Türkiye'de ekolojik ayak izinin belirleyicileri. Erdem, H.F. (Ed.), iktisat Seçme Yazılar içinde (ss. 133-155). Trabzon: Celepler Matbaacılık.

Bello, M.O., Solarin, S.A. \& Yen, Y.Y. (2018). The impact of electricity consumption on CO2 emission, carbon footprint, water footprint and ecological footprint: The role of hydropower in an emerging economy. Journal of Environmental Management, 219, 218-230.

Bera, A. \& Jarque, C. (1981). Efficient tests for normality, heteroscedasticity, and serial independence of regression residuals: Monte carlo evidence. Econometrics Letters, 7, 313-318.

Breusch, T.S. \& Pagan, A.R. (1979). A simple test for heteroscedasticity and random coefficient variation. Econometrica, 47(5), 1287-1294.

Çamurlu, S. \& Erilli, Necati, A. (2019). Kantil regresyon analizinde bootstrap tahmini. Erciyes Üniversitesi Fen Bilimleri Enstitüsü Dergisi, 35(2), 16-25.

Davino,C., Furno,M. \& Vistocco, D. (2014). Quantile regression theory and applications. United Kingdom: John Wiley \& Sons.

Dietz, T. \& Rosa, E.A. (1997). Effect of population and affluence on CO2 emissions. Proc. Natl. Acad. Sci. Amerika Birleşik Devletleri, 94(1), 175-179.

Dietz, T., Rosa, E.A. \& York, R. (2007). Driving the human ecological footprint. Frontiers in Ecology and the Environment, 5(1), 13-18.

Ehrlich, Paul R. \& Holdren, J.P. (1971). Impact of population growth. American Association for the Advancement of Science, 171(3977), 1212-1217.

Global Footprint Network. (n.d.). How the footprint works. Retrieved from https://www. footprintnetwork.org/our-work/ecological-footprint/

Grooten, M. \& Almond, R.E.A. (Eds.). (2018). Living planet report-2018: Aiming higher. WWF, Gland, Switzerland. 
Hayden, A. \& Shandra, J.M. (2009). Hours of work and the ecological footprint of nations: An exploratory analysis. Local Environment, 14(6), 575-600.

Jia, J., Deng, H., Duan, J. \& Zhao, J. (2009). Analysis of the major drivers of the ecological footprint using the STIRPAT model and the PLS method - A case study in Henan Province, China. Ecological Economics, 68(11), 2818-2824.

McMillen, P. D. (2013). Quantile regression for spatial data springer. New York: Springer.

Ramsey, J. (1969). Tests for specification errors in classical linear least-squares regression analysis. Journal of the Royal Statistical Society. Series B (Methodological), 31(2), 350-371.

Rosa, E.A., York, R. \& Dietz, T. (2004). Tracking the anthropogenic drivers of ecological impacts. AMBIO: A Journal of the Human Environment, 33(8), 509-512.

Tang, W., Zhong, X. \& Liu, S. (2011). Analysis of major driving forces of ecological footprint based on the STRIPAT model and RR method: A case of Sichuan Province, Southwest China. Journal of Mountain Science, 8(4), 611-618.

University of Groningen. (2016). Penn world table. Retrieved from https:// www.rug.nl/ggdc/ productivity/pwt/

Wackernagel, M. \& Rees, W. (1996). Urban ecological footprints: Why cities cannot be sustainable And why they are a key to sustainability. Environmental Impact Assessment Review, 16(4), 223- 248.

Wang, S., Zhao, T., Zheng, H. \& Hu,Z. (2017). The STIRPAT analysis on carbon emission in Chinese cities: An asymmetric laplace distribution mixture model. Sustainability, 9(12), 1-13.

World Wide Fund for Nature-Duetschland. (2016). Living planet report 2016. Retrieved from https:// www. wwf. de/fileadmin/fm-wwf/Publikationen-PDF/WWF-LivingPlanetReport-2016Kurzfassung. pdf

York, R., Rosa, E.A. \& Dietz, T. (2003a). STIRPAT, IPAT and IMPACT: Analytic tools for unpacking the driving forces of environmental impacts. Ecological Economics, 46(3), 351-365.

York, R., Rosa, E.A. \& Dietz, T. (2003b). A rift in modernity? Assessing the anthropogenic sources of global climate change with the STIRPAT model. International Journal of Sociology and Social Policy, 23(10), 31-51.

York, R., Rosa, E.A. \& Dietz, T. (2003c). Footprints on the earth: the environmental consequences of modernity. American Sociological Review, 68(2), 279-300. 


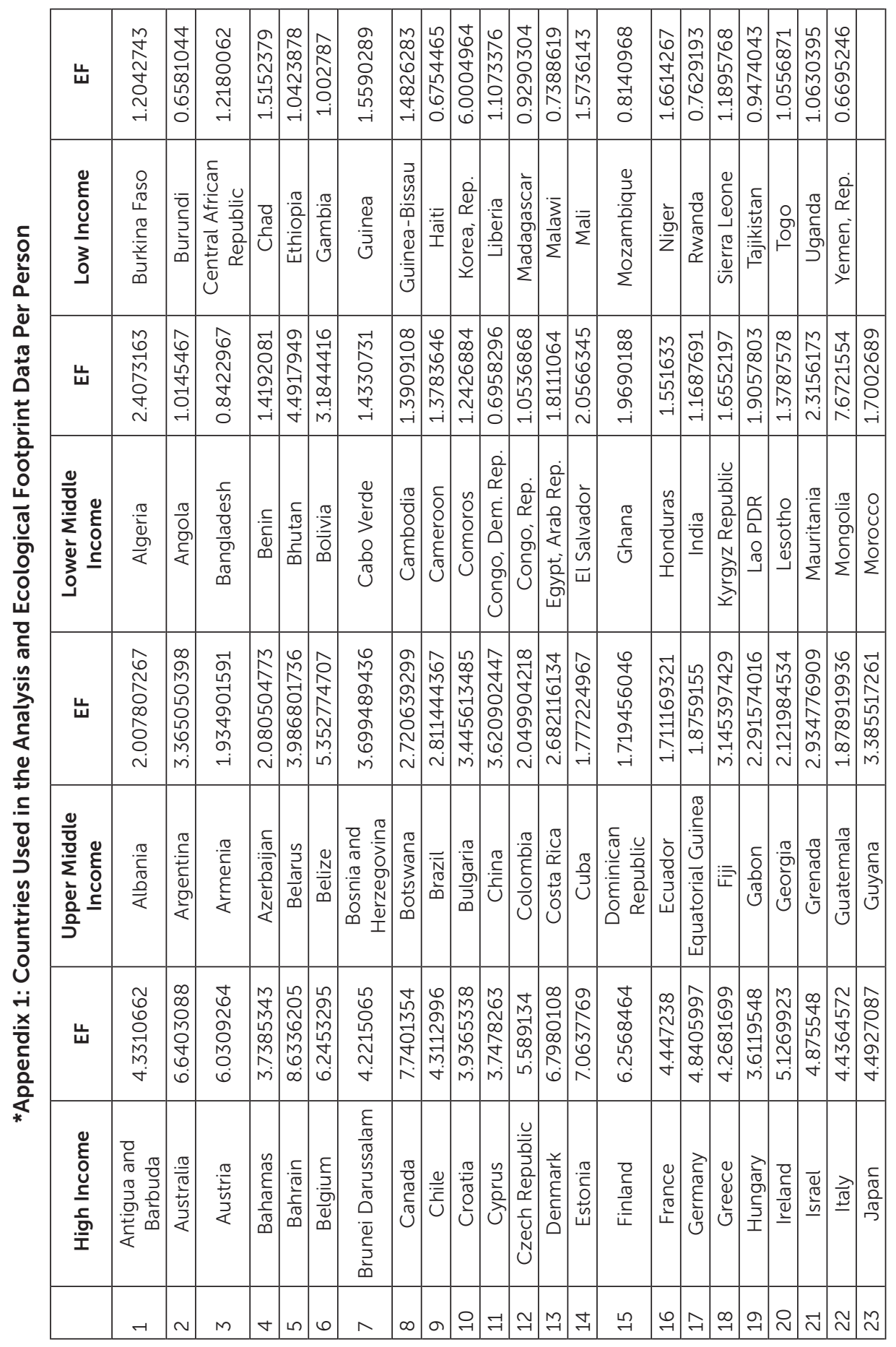




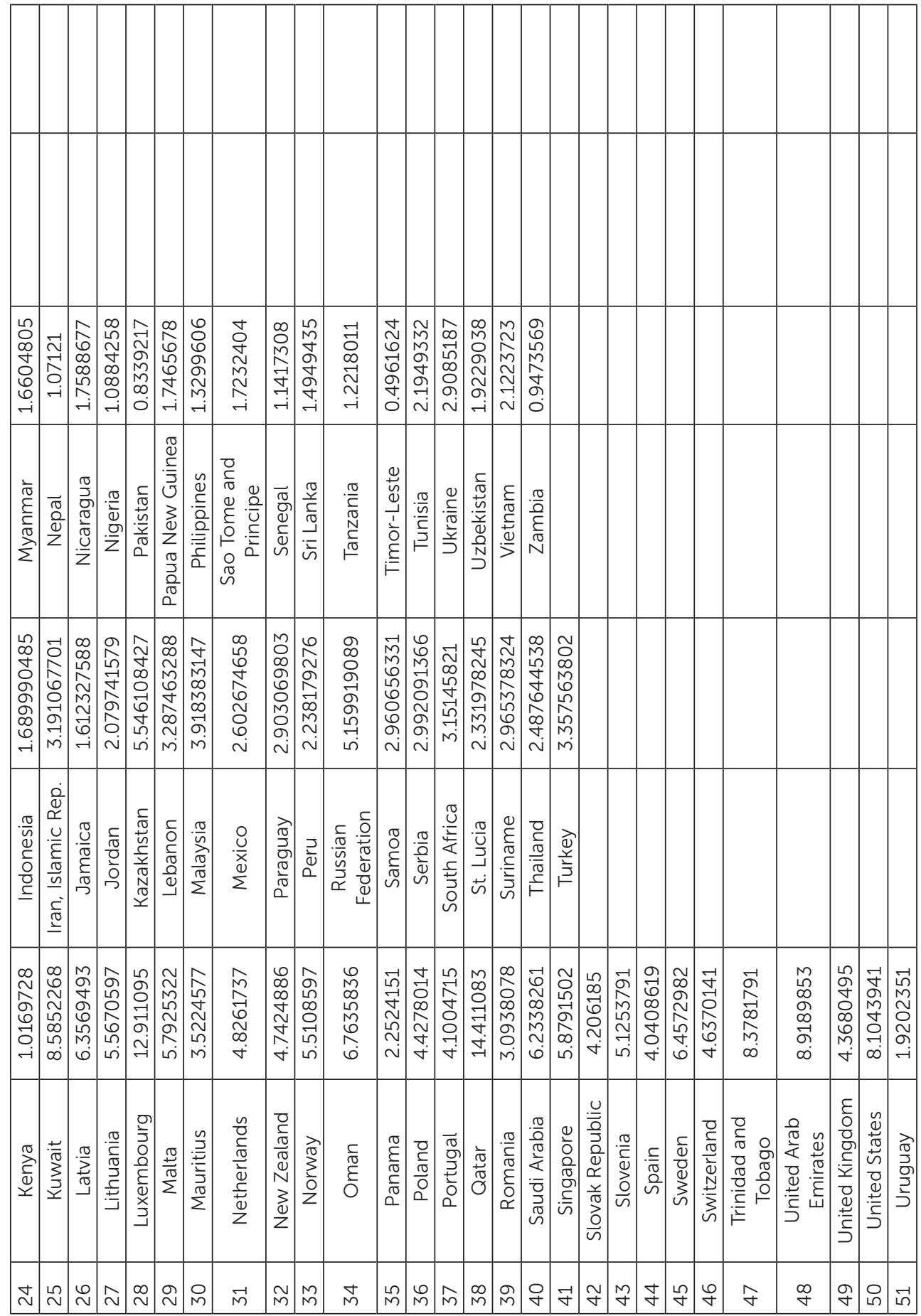

